\title{
Review
}

\section{Ring shake in chestnut (Castanea sativa Mill.): State of the art}

\author{
Patrick Fonti $^{\mathrm{a} *}$, Nicola Macchioni ${ }^{\mathrm{b}}$ and Bernard Thibaut ${ }^{\mathrm{c}}$ \\ ${ }^{a}$ WSL Swiss Federal Research Institute, Sottostazione Sud delle Alpi, Via Belsoggiorno 22, \\ Casella postale 57, 6504 Bellinzona, Switzerland \\ ${ }^{\mathrm{b}}$ Istituto per la ricerca sul legno, Consiglio nazionale delle ricerche, Via A. Barazzuoli 23, 50136 Firenze, Italy \\ ${ }^{c}$ Université Montpellier II Science \& Techniques du Languedoc, Laboratoire de Mécanique \& Génie Civil, \\ Place Eugène Bataillon, Bât. 13 - Case Courrier 081, 34095 Montpellier Cedex 5, France
}

(Received 22 January 2001; accepted 1 October 2001)

\begin{abstract}
Too often chestnut wood (Castanea sativa Mill.) becomes economically uninteresting because of the high risk of ring shake to which this species is prone. For more than twenty years chestnut ring shake has been the subject of studies undertaken in an effort to understand its underlying causes and mechanisms. Since not all aspects of the phenomenon have been sufficiently studied at the present time, ring shake has not yet been completely elucidated. However, it is possible to outline a general framework of the phenomenon and advance preliminary ideas on the causes that contribute to the development of this type of fracture. This article summarises the current state of knowledge, discusses the possible causes and proposes measures to reduce the risk of ring shake occurrence in chestnut.
\end{abstract}

ring shake / Castanea sativa Mill. / wood / residual stresses / mechanical strength

Résumé - La roulure du châtaignier (Castanea sativa Mill.): connaissances actuelles. Trop souvent le bois de châtaignier (Castanea sativa Mill.) perd son intérêt économique à cause du haut risque de roulure qui affecte cette espèce. Depuis plus de vingt ans la roulure du châtaignier fait l'objet de plusieurs études vouées à la compréhension des causes et des mécanismes qui conduisent à sa formation. À l'état actuel tous les aspects n'ont pas été suffisamment étudiés pour que l'on puisse considérer la roulure comme un phénomène complètement élucidé. Malgré cela, un cadre général du phénomène peut être esquissé et des premières réflexions sur les causes qui mènent à l'apparition de ce type de fracture peuvent être avancées. Cet article résume l'état des connaissances acquises à ce jour, discute les causes possibles et propose des mesures afin de diminuer le risque d'apparition de la roulure chez le châtaignier.

roulure / Castanea sativa Mill. / bois / contraintes résiduelles / résistance mécanique

\footnotetext{
* Correspondence and reprints

Tel. +41 9182152 33; Fax. +41 9182152 39; e-mail: patrick.fonti@wsl.ch
} 


\section{INTRODUCTION}

Chestnut (Castanea sativa Mill.) is widespread in about 15 Mediterranean and Central European countries with a total cover of more than 2 million hectares [12]. Until the mid-20th century, chestnut was of fundamental importance to the economy and to the subsistence of rural populations. Then, with the decline of the rural economy and the onset of diseases, the management of chestnut forests ceased. However, chestnut timber possesses a pleasant appearance, high durability and good mechanical properties. Since it can be processed using modern manufacturing or industrial techniques (laminated, veneer, lumber, non-structural Glulam and solid wood panels) suitable for such added-value sectors as furniture, equipment and carpentry, it is one of the most versatile and appreciated woods growing in Europe [12]. One of the main problems to be taken into account is the risk of ring shake, whose occurrence greatly reduces the value of the timber assortment. In the worst case, the incidence of ring shake is so high that only few logs of a stand can be brought to the sawmill. With ring shake as the main obstacle to the economical exploitation of chestnut wood, today's forest managers are not ready to invest in chestnut forests. As a result chestnut wood, tends to be a largely neglected natural renewable resource.

Ring shake is a widespread phenomenon affecting a great number of species of both softwood and hardwood and is found in trees grown in temperate and tropical climates. In general, however, it afflicts only a very small proportion of trees. Irrespective of whether the cracks occur after felling or cross cutting, they are nearly always radial cracks. Some species are more heavily prone to ring shake occurrence (such as some species of the genus Quercus, Juglans, Abies, Pseudotsuga, Tsuga and Eucalyptus [19]), but chestnut is probably the most widely affected species, since it is nearly impossible to find a forest plot without any ring shaken log.

Research into ring shake is aimed at understanding the factors that cause the fracture in order to evaluate new preventive measures that will minimise the risk of occurrence. This would permit the reintroduction of a "driving force" for chestnut forest management.

This review summarises the fragmentary acquired knowledge currently available about ring shake in chestnut wood and discusses the causes of the phenomenon. We also propose measures for decreasing the risk of ring shake occurrence. In doing so we intend to open up new discussions of the subject and provide a solid base of knowledge for future investigations.

\section{FUNDAMENTALS OF CHESTNUT RING SHAKE}

\subsection{Definition}

At the end of the 1980s Chanson [16] and Cielo [19] published objective definitions of ring shake, distinguishing between a description of the phenomenon and its causes. Discarding indications of the causes or the process that lead to ring shake, since none of the several suggested explanations was widely accepted, they simply defined ring shake by its appearance, i.e. a separation in the tangential plane that occurs in the ligneous tissues along the annual growth ring.

\subsection{Where and when ring shake appears}

Ring shake occurs mainly in stem wood. In some cases it can also appear in the big branches of aged trees, but this is quite rare. It usually does not occur in roots. Opinions diverge on whether ring shake is already present in standing trees, with several authors believing that it might be at least partially present in living trees [19, 22]. Radial ultrasonic measurement of stems evidenced that waves propagate more slowly in stems which displayed ring shake immediately after felling [35]. This may be due to a break in wave propagation caused by the fracture. But other factors, such as a decrease in the radial moduli of elasticity of trees prone to ring shake, could also explain the slowing of wave propagation [51]. Conversely, other authors [18] believe ring shake to be found immediately after felling results from the releasing of growth stresses in the stem when the stem is crosscut. At all events, new ring shake may occur after the cutting of the tree either as a result of the logs being dried and sawn or even as a result of the installation of wood products [18]. After felling, two different trends of crack development and propagation are observed on the logs, depending on the occurrence of ring shake displayed by the freshly felled stem. If the stem displays some ring shake after felling, the wood drying and wood heating process tends to increase its size or number; conversely, if the stem displays radial cracks rather than ring shake, logs cut from it are inclined to form and extend radial cracks $[1,10,18,19,25]$. In some cases newly formed radial cracks may also change direction, going off a tangent to generate new ring shake [51]. 


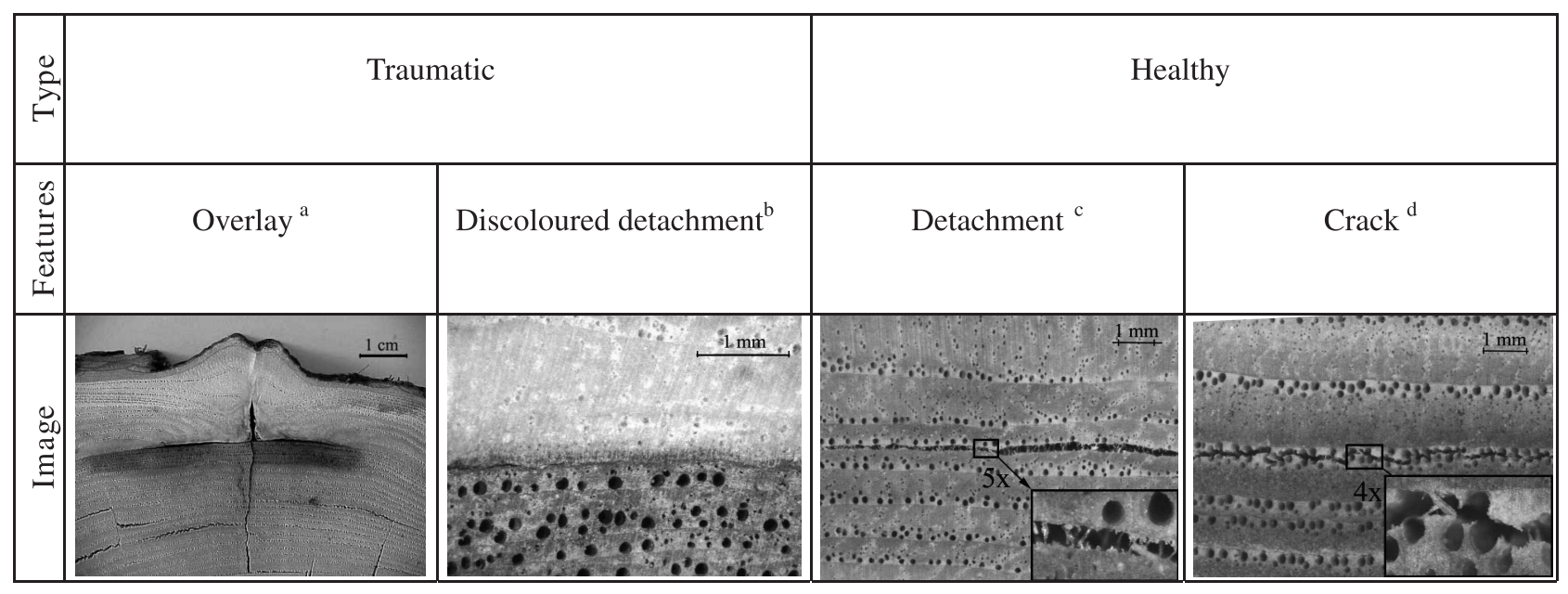

Figure 1. Types and features of fractures viewed in cross section. (a) Overlay of new cells on dead tissues due to a physiological reaction to wound on cambium after trauma. Appears on standing trees. (b) Discoloured detachment between cells at the ring boundary between the earlywood zone of the annual ring and the latewood zone of the previous ring; develops as a consequence of compartmentalisation after trauma leading to discoloration and to local decay with detachment. May develop in standing trees. (c) Detachment between cells at the ring boundary between the earlywood zone of the annual ring and the latewood of the previous one. Mainly characteristic of ring shake that appears as the wood dry. (d) Crack across cell walls in the earlywood zone. Appears predominately in fresh green wood.

\subsection{Types and features of fractures}

In his observations Chanson [17] distinguished two types of ring shake: "traumatic" ring shake and the more common "healthy" ring shake. By definition, "traumatic" ring shake is always related to visible anomalies in the wood tissue, whereas with "healthy" ring shake, splitting appears to be unrelated to any recognisable anatomical perturbation. Two fracture features can be distinguished in traumatic ring shakes (figure 1): the first, which we have called "overlay", is characterised by scar tissue superposed on dead cells without any connection between them [16]. It is also possible for ring shake to arise indirectly as a consequence of trauma. In this case a process of compartmentalisation appears, leading to discoloration and decay in the surrounding area [22], and ring shake may occur in the wood tissue as a detachment between the anomalous cells. We called this second feature "discoloured detachment". The "healthy" type also displays other fracture features, depending on the manner in which the wood cells are separated (figure 1). A first feature of observed ruptures is detachment in the compound middle lamella layer between cells. This kind of shake mainly develops at a ring boundary [61] and is typical of ring shake caused by wood drying [58]. We named this feature "detachment". The second feature of fractures that occur predominately in ring shake developed in fresh green wood immediately after the tree-felling consists of a crack that develops across the cell walls of the earlywood vessels [58]. This latter feature was called "crack" by virtue of evidence of a break in the wood cell wall opposing it to the detachment feature, where the material seems more to be "unglued".

\section{DISTRIBUTION AND INCIDENCE}

\subsection{In relationship to environmental and anthropogenic factors}

Several authors have investigated the relationship between environmental factors and ring shake. One of these is Chang [15], who, in his general review of ring shake in different species, pointed out that ring shake is not determined by a unique element, but it is rather the result of several factors that act together. One of these factors might be temperature, since it is hypothesised that frost or sudden temperature change might open fractures in wood. Observations on chestnut stands partly support 
this hypothesis [41]. According to Chang, chestnuts growing in cold zones seem to be more affected by ring shake than those growing in temperate zones. This theory is contested by results obtained by Boetto [10] and Cielo [19], which showed that exposition and elevation have no effect on ring shake intensity.

A further element thought to play a role in the ring shake process is soil. In his study on ring shake in oak, Lachaussée [48] reported that the problem occurs less frequently in trees growing in fertile soils than in trees growing in poor ones. Observations reported in other studies on chestnut support this hypothesis, even though the differences in the incidence of ring shake are only slight $[4,41,57]$.

In addition to environmental conditions, anthropogenic factors have also been reported to be involved in the ring shake process. In fact, although the defect is present in every management system, be it coppice stand, high forest (plantation or natural) or orchards, it was observed that the risk of ring shake in chestnuts growing in high forests is minor [18, 22, 41]. In addition, a recent study by Amorini et al. [4] revealed that in coppice stands a positive relationship exists between a high silviculture intensity and a lower risk of ring shake formation.

\subsection{In the chestnut distribution area}

As yet there has been no comprehensive study of ring shake propagation across all areas in which chestnut is grown, but many indicators of occurrence in mature stands allow us to deduce that in the Mediterranean area at least, ring shake occurs wherever chestnut grows. Investigations in different areas of southern France give indications of regional differences for both "traumatic" (more frequent in Mediterranean regions) and "healthy" ring shake (more abundant in Limousin then in Périgord, for example) [57]. Fragmentary investigations conducted principally in France and Italy support this belief (table I), even if ring shake is quite rare in some localised areas.

\subsection{Among chestnut trees}

Several authors have undertaken analyses in an effort to identify tree characteristics that will enable us to differentiate ring shaken trees from unshaken ones. In general, it proved very difficult to identify such characteristics for trees grown on the same stands: in practice ring shake not only occurs both in trees that display an equilibrated morphological structure and in trees that do not $[10,17,19]$, but also in dominant and dominated trees $[4,10,19,54]$. Likewise, bark morphology and chestnut blight (Cryphonectria parasitica) do not seem have any impact on fracture development [19]. However, a few authors observed that old and/or big trees might be more inclined to develop ring shake [1, 10, 17, 19, 22, 41, 54]. Results from further investigations using the multivariate analysis method bear out this trend [17, 25, 54].

Analysis of ring shake occurrence within a single coppice stand indicates that the phenomenon is not randomly distributed throughout the tree population, but is instead concentrated over a number of stools. In particular it was observed that the incidence of ring shake among all shoots of the same stool tends to be the same [25, 54]. Considering the ring shake incidence of the standards (shoots that stay for two rotation periods), this appears somewhat remarkable. In fact Macchioni and Pividori [54] observed in their study that all the standards displayed ring shake, even if all the other shoots in the same stool did not. The authors also observed that ring shake in standards mainly occurs near the annual rings, corresponding to the years of the cut of the previous coppice stand.

\subsection{Within trunks}

In general, it has been noticed that longitudinal ring shake occurs mainly at the base of the stem $[1,4,10$, 17-19, 51], while radial ring shake (from the pith to the bark) is distributed with unimodal frequency in the middle third of the radius $[1,10,11,25,54]$. It has been observed that drying increases ring shake intensity and that the new distribution is slightly shifted towards the bark [25]. The defect appears to be randomly distributed with respect to the cardinal points in the stem cross-section, even in a stand situated on a slope [25]. It was observed that the occurrence of ring shake is concentrated in a limited number of rings which are characterised by a narrow radial current increment followed by larger rings, i.e. in trees that have grown irregularly $[4,17,22,25,54]$.

\section{TOWARDS THE CAUSES}

We can define the cause of a specific defect as the antecedent event, condition, or characteristic that is necessary for the defect to occur at the moment that it did [60]. The concept of causation is commonly characterised by the assumption that there is a one-to-one relationship 
Table I. Incidence of ring shake observed in various studies.

\begin{tabular}{|c|c|c|c|c|c|}
\hline \multirow[t]{2}{*}{ Stand location } & \multirow[t]{2}{*}{ Sample } & \multirow[t]{2}{*}{ Surveying Method } & \multicolumn{2}{|c|}{$\%$ ring shaken stem per plot per region } & \multirow[t]{2}{*}{ Source } \\
\hline & & & on green wood ${ }^{\mathrm{a}}$ & after drying $^{\mathrm{b}}$ & \\
\hline Languedoc- Roussillon (F) & $\begin{array}{l}94 \text { shoots taken from } \\
9 \text { stands }\end{array}$ & $\begin{array}{l}\text { Observations on two increment } \\
\text { cores }\end{array}$ & $\begin{array}{c}60 \\
\text { (from } 17 \text { to } 90 \\
\text { depending on stand) }\end{array}$ & & [51] \\
\hline Bretagne (F) & $\begin{array}{l}480 \text { shoots taken } \\
\text { from } 24 \text { stands }\end{array}$ & $\begin{array}{l}\text { Observation at the base of the } \\
\operatorname{logs}\end{array}$ & $\begin{array}{c}40 \\
\text { (from } 5 \text { to } 100 \\
\text { depending on stand) }\end{array}$ & - & [11] \\
\hline $\begin{array}{l}\text { Languedoc, Roussillon Limousin } \\
\text { and Perigord }(\mathrm{F})\end{array}$ & & & & & [57] \\
\hline $\begin{array}{l}\text { Pyrénées Orientales, Cévennes, } \\
\text { Limousin and Périgord (F) }\end{array}$ & $\begin{array}{l}285 \text { shoots taken } \\
\text { from } 37 \text { stands }\end{array}$ & $\begin{array}{l}\text { Observation at the base of the } \\
\operatorname{logs}\end{array}$ & 42 & - & [18] \\
\hline $\begin{array}{l}\text { Aude, Aveyron, Hérault, Lot, } \\
\text { Tarn, Tarn and Garonne (F) }\end{array}$ & $\begin{array}{l}156 \text { shoots taken } \\
\text { from } 6 \text { regions }\end{array}$ & $\begin{array}{l}\text { Observation at the base of the } \\
\operatorname{logs}\end{array}$ & 39 & - & {$[18]$} \\
\hline Piemonte (I) & $\begin{array}{l}45 \text { shoots taken from } \\
3 \text { stands ( } 15 \text { shoots } \\
\text { each) }\end{array}$ & $\begin{array}{l}\text { Observation on } 5 \mathrm{~cm} \text { thick disks } \\
\text { taken at different heights, } \\
\text { starting from the base of the logs }\end{array}$ & 53 & 53 & [19] \\
\hline Piemonte (I) & $\begin{array}{l}82 \text { shoots taken from } \\
3 \text { regions }\end{array}$ & $\begin{array}{l}\text { Observation on } 5 \mathrm{~cm} \text { thick disks } \\
\text { taken at different heights, } \\
\text { starting from the base of the logs }\end{array}$ & - & 36 & {$[1]$} \\
\hline Piemonte (I) & $\begin{array}{l}50 \text { shoots taken from } \\
2 \text { regions }\end{array}$ & $\begin{array}{l}\text { Observation on } 5 \mathrm{~cm} \text { thick disks } \\
\text { taken at different heights, } \\
\text { starting from the base of the logs }\end{array}$ & - & 38.5 & {$[10]$} \\
\hline Piemonte (I) & 0.3 ha coppice stand & $\begin{array}{l}\text { Observation on } 5 \mathrm{~cm} \text { thick disks } \\
\text { taken from the bases of } \\
300 \text { shoots }\end{array}$ & - & $\begin{array}{l}38 \text { (of shoots) } \\
96 \text { (of standard) }\end{array}$ & {$[54]$} \\
\hline Toscana, Lazio and Piemonte (I) & $\begin{array}{l}35 \text { shoots taken from } \\
4 \text { stands }\end{array}$ & $\begin{array}{l}\text { Observation on } 5 \mathrm{~cm} \text { thick disks } \\
\text { taken at different heights, } \\
\text { starting from the base of the logs }\end{array}$ & - & 40 & {$[4]$} \\
\hline Ticino $(\mathrm{CH})$ & 0.1 ha coppice stand & $\begin{array}{l}\text { Observation on } 5 \mathrm{~cm} \text { thick disks } \\
\text { taken from the bases of } 93 \text { shoots }\end{array}$ & 54 & 68 & {$[24]$} \\
\hline
\end{tabular}

${ }^{a}$ Ring shake observed immediately or a few days after the felling of the tree.

${ }^{\mathrm{b}}$ Ring shake observed on dried wood $(<15 \%)$.

between the observed cause and the effect. But with experience and research into the process that causes ring shake, we have been persuaded that ring shake results from a complexity of factors that act in concert. If we consider the formation of ring shake from a mechanical point of view, the fracture appears in the wood when the radial strength is weaker at a given time and in a given place than the stress acting in that direction. From this standpoint, strength and stress are the key players in the development of a rupture. Thus, we can analyse the formation of ring shake by focusing our attention on the equilibrium between these two central factors.

\subsection{Weak radial wood strength}

Chestnut is widely known to be a very fissile wood. Its strength perpendicular to the fibre is almost half that of oak (table II) [12]. Many studies of the transversal mechanical strength of chestnut have shown that trunks with ring shake display a lower average radial strength value than those without ring shake [4, 20, 21, 32, 51-53, 63]. This kind of evidence, however, does not explain the entire phenomenon. In fact the experiments carried out did not establish any statistical value of performance to 
Table II. Ring shake-relevant characteristics of chestnut wood

\begin{tabular}{lccccc}
\hline Direction & E-modulus & $\sigma_{\text {strength }}$ & $\begin{array}{c}\text { Instantaneous deformations } \\
\text { on stem surface }\end{array}$ & $\begin{array}{c}\text { Hygrothermal deformations } \\
{[\%]}\end{array}$ & Drying deformations \\
\hline Longitudinal & {$[\mathrm{MPa}]$} & {$[\mathrm{MPa}]$} & $-0.095^{\mathrm{a}}$ & \pm 0.1 & -0.33 \\
Tangential & - & - & $0.110^{\mathrm{b}}$ & From 0.4 to 0.6 & -8.08 \\
Radial & - & - & $-0.059^{\mathrm{b}}$ & -0.1 & -3.44 \\
Source & $1400-2400 \times 100$ & $7-16 \times 100$ & ${ }^{\mathrm{a}}[63]$ & {$[9,38,42]$} & {$[51]$} \\
& {$[51]$} & {$[51]$} & $\mathrm{b}[43]$ & & \\
\hline
\end{tabular}

distinguish ring shaken trees from unshaken ones. It was also observed that wood strength distribution is not homogeneous along the radius. Results from various studies indicate that radial wood strength decreases from the pith to the bark $[32,53]$, probably as a result of decreasing specific density from the pith to the bark, which may be in relationship with the radial wood strength.

\subsubsection{Individual tree effect (genetic factors?)}

The fact that chestnut wood is extremely weak in some cases might be primarily due to genetic causes. Two main observations lead us to suppose that genetic factors regulate wood strength, and so indirectly ring shake formation. First, ring shake is not randomly distributed within a single stand, but is instead concentrated over several trees (stools) that are particularly prone to this defect. Second, fracture tests performed with different trees grown in the same stand revealed that strength is principally an intrinsic characteristic of the individual $[20,51]$. In particular, it is common for all the shoots of the same coppice stump to behave in the same way [25, 54]. These observations suggest that a link exists between genetic factors and ring shake formation. This hypothesis is supported, although not proven, by results from various studies aiming to establish a link between radial strength and genetic factors [30-32, 63].

\subsubsection{Soil effect?}

It has been observed that radial strength is lower in those stands where the soil is particularly poor in calcium and other cations [63]. In fact, it is claimed that the binding capacity of calcium cations can strengthen the middle lamellas, as described by the "egg-box model" developed by Grant et al. [37]. Several studies have been performed to clarify the relationship between calcium contents in the soil and in trees, with a special regard to ring shake incidence $[33,34,49,50,59,63,66,67]$. The results obtained indicate a link between very low calcium contents and ring shake incidence, yet without providing the evidence for a direct relationship between them. We must also underline that as a species, chestnut is known to be intolerant of calcareous soils: it is possible that the problem is due to difficulties in calcium absorption, rather than the absolute amount of calcium.

\subsection{The stresses in wood}

Apart from the external and temporary stresses that may act on trees and installed wood, such as wind and snow, three mechanisms could be responsible for the stresses that cause splitting: the instantaneous release of certain growth stresses as a result of tree-felling, stemcrosscutting and log-sawing [5, 47]; the additional relieving of stresses that is observed when wood is heated (hygrothermal recovery) [38, 40, 45, 46]; and the stresses generated as a consequence of anisotropical shrinkage of wood. Both instantaneous stress release and hygrothermal recovery seem to be related to the rheological conditions of wood cell maturation and of morphological tree growth [39, 64], while drying stress originates in the moisture change process in wood and is linked to the drying process parameters.

\subsubsection{Growth stresses}

The term "growth stress" refers to the distribution of mechanical stresses that develop in stems as the tree grows in diameter and height. This is the result of the superposition of support stresses and maturation stresses 
$[27,28]$. Support stresses are caused by the self weight supported by the tree; their distribution in the stem depends heavily on the historical evolution of the tree-loading and on the existing geometrical and architectural situation [27] and are difficult to estimate. More relevant to the formation of ring shake are maturation stresses. This kind of stress arises during the maturation of new cells. Just after differentiation, as cells mature, they are subjected to bio-mechanical transformations that occur at the $\mathrm{S} 2$ cell wall level $[7,13]$. As a result, cells tend to modify their dimensions and generate stresses in wood. Several authors have proposed models describing the distribution of maturation stresses within the stem $[5,6$, $26,28,47]$. Using these models, Thibaut et al. [63] gave a qualitative illustration of how longitudinal, tangential and radial stresses are distributed in the stem (figure 2). Near the bark there is longitudinal tension, tangential compression and no radial stress, while near the pith there should be a high level of longitudinal compression and both radial and tangential tension. Wood is mostly prone to break in tangential or radial tension. So end splitting linked to growth stress relief must occur near the pith [47] and should take the form of radial cracks. This is the case even in chestnut for which has always had at

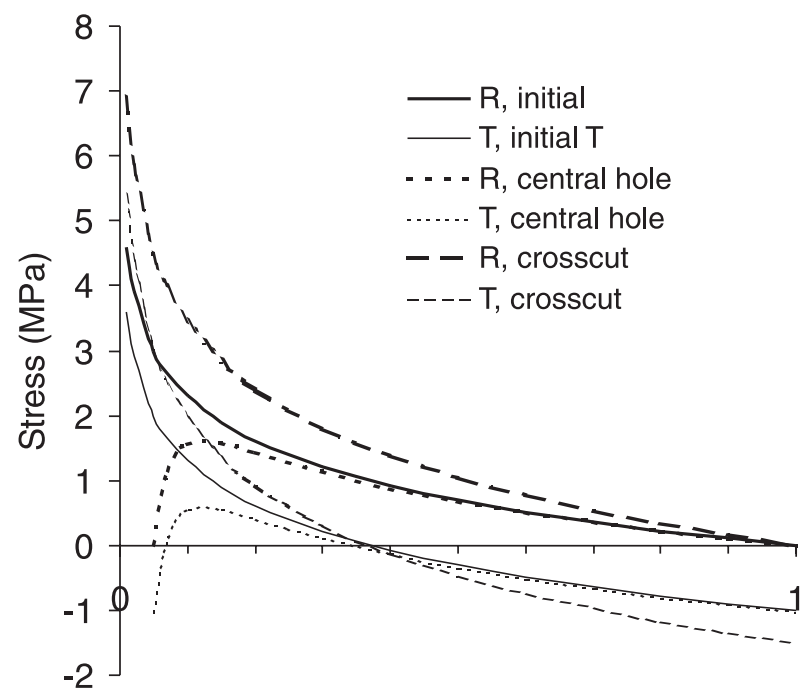

Relative radius $(\mathrm{r} / \mathrm{R})$

Figure 2. Transverse growth stresses at log ends before [42] and after crosscutting, and after the appearance of small heart cracks. The model assumes an axisymmetric, homogeneous and transversally isotropic log, constant maturation stress (Kübler's model [47]) and the heart cracks are made equivalent to a central hole [40] (here $5 \%$ of log diameter). least a small crack running from the pith outwards [57]. This also suggests that no ring shake should occur near the bark, as was observed [11]. After the first small radial crack occurs, stress distribution inside the log is changed and maximum radial stress is then located between the end of the crack extension and the middle of the radius [9, 38]. This probably explains the numerous observations of ring shake distribution along the radius cited before.

Chestnut coppice shoots reveal longitudinal surface strain stress values (table II) similar to other broadleaved species like beech, eucalyptus and poplar [29]. No substantial interregional differences in measured stress have been observed and coppice management does not seem to favour higher values except for at the base of curved trunks [63]. In symmetrical stools in fact, longitudinal deformation is usually constant along the circumference of the shoots, the value being characteristic of each single [65]. Some stools however displayed stem's sector with longitudinal deformation 5 times greater than the "standard" values $[21,29,65]$. This phenomenon comes back to the heterogeneous distribution of reaction wood, which possesses a particularly high maturation stress, in the stem. The same authors also observed that sectors characterised by small annual rings have a lower longitudinal surface deformation value than sectors with large annual rings. Although differences were observed between trees, no clear relationship between high longitudinal surface strain and ring shake occurrence was found. The same statement is also true for the transverse stresses measured on the same sample of trees $[63,65]$.

\subsubsection{Hygrothermal recovery}

Locked strains in trees are partially released by cutting specimens from the tree, and more completely through hygrothermal recovery, by boiling them in a green state, so as to exceed the softening point of lignin $[39,45,46]$. Hygrothermal recovery evidences the effect of the transverse strains [42] (table II). As a result hygrothermal recovery causes the further growth or new development of either radial cracks in some trees or of ring shakes in others $[57,63]$. This indirectly proves that residual stresses that are distributed like growth stresses are prone to develop ring shake and that there are two populations of logs: those that extend heart checks without ring shakes and those that extend ring shakes leaving the first heart shakes at their low extension. 


\subsubsection{Drying stresses}

During drying, timber moisture content decreases from a very high level to a relatively low level. When the bounded water of the cell walls is removed too, wood volume begins to change an anisotropically, thereby generating drying stresses. Compared to other similar species, chestnut wood does not display any anomalous shrinkage (table II) or unusual microfibril angle [62], which might justify its high occurrence of ring shake. In his study, however, Leban [51] observed that within the same radial section, ring shaken annual rings display a double radial shrinkage compared to the mean radial shrinkage of the whole radius. In addition, tangential shrinkage was always found to be higher in the annual ring preceding the ring shaken one. Fioravanti [23] also noticed different shrinkage in wood: he observed that there is a different longitudinal shrinkage in the earlywood and latewood areas of the same annual ring. This gradient was particularly pronounced in rings characterised by a small annual increment surrounded by larger rings. All these observations lead us to assume that the structure of the single annual ring may influence local shrinkage and consequently could further favour the development of ring shake in specific annual rings.

\section{CONCLUDING REMARKS}

The phenomenon of ring shake appears with a high level of variability, making comprehension of the process leading to ring shake a hard task. However, by combining consistent results from different studies, we are able to draw up a possible scenario for ring shake formation. The key elements are radial wood strength and wood stresses. From a mechanical point of view, the mechanism that induces ring shake is simple: tangential separation occurs if radial wood strength is weaker than the wood stress acting in that direction. It is more difficult to prove where and when this condition is achieved. Both those elements are regulated by several factors as described in figure 3.

It has been known for a long time that traumatic ring shake is trauma-related in origin and that this type of fracture is not the most important facet of the chestnut ring shake problem because we know causes and possible remedies [18]. The situation with healthy-type ring shake is more problematic, however. On the basis of what we have described above, we can assert that the phenomenon of healthy ring shake in chestnut is principally linked

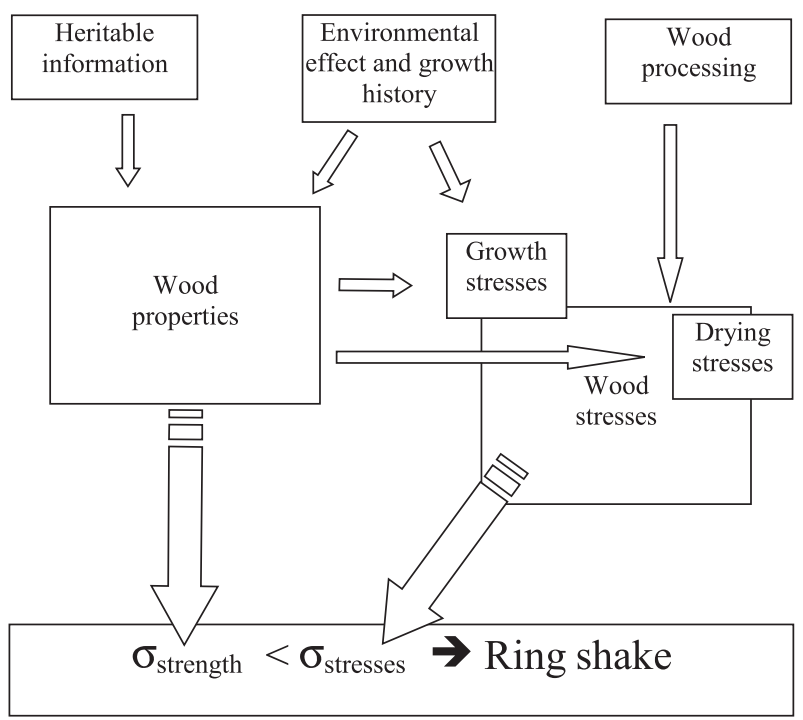

Figure 3. Diagram of ring shake formation process. The key elements in ring shake formation are radial wood strength $\left(\sigma_{\text {strength }}\right)$ and wood stresses $\left(\sigma_{\text {stresses }}\right)$. Radial wood strength results from the interaction between the anatomical, chemical and physical characteristics of wood, which are determined by genetic constitution, tree environment and tree history. The same is true as for wood stresses. In addition, wood stresses depend on the stage of wood processing, whereby stresses can be relieved (growth stresses) or newly generated (hygrothermal recovery and drying stresses). We draw attention to the fact that wood properties change in the stem as trees grow in size and height, thereby establishing a dynamic and complex relationship between the aforementioned elements playing a role in the development of ring shake.

to the weak wood strength of this species. It is striking that chestnut wood tends to develop tangential splits while most of the other wood species form radial fractures. This particular behaviour of chestnut wood and the fact that it is the wood most commonly affected by ring shake suggest that in the radial direction this type of timber might be particularly weak compared to other species. Ferrand [22] hypothesised that this weakness might be brought back to the singularities in the structure of chestnut wood (figure 4). Two features in particular are characteristic of chestnut wood anatomy. It displays a ring-porous wood structure, in which the earlywood vessels are distinctly larger than the latewood ones, generating a soft zone rich in cavities and a very distinct and homogeneous interface between successive rings. Second, being of monoseriate type, radial rays that act as radial reinforcing fibres $[2,3,8,14,44,55,56]$ can only partially fulfil this function in chestnut wood. Thus, it is easy for tangential cracks to propagate. In contrast, the 


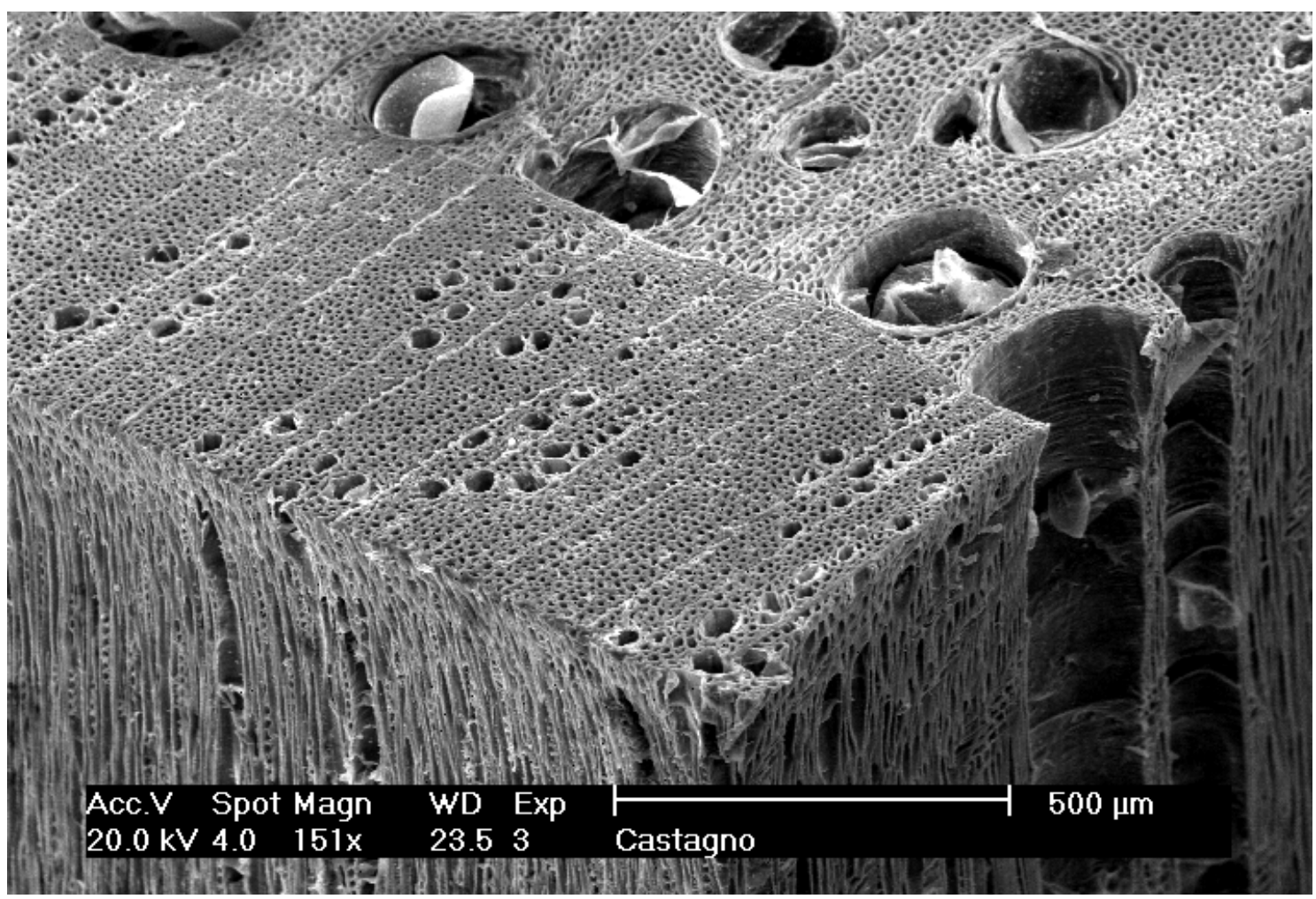

Figure 4. Structure of chestnut wood. Electronic scanning microscope image. Characteristic of chestnut wood are the ring porous wood structure with large earlywood vessels and the thin monoseriate radial rays.

radial cracks that usually form along radial rays have to cross both the soft earlywood and the rigid latewood zones, which offer resistance to fracture propagation. Depending on the balance between radial and tangential strength, will it develop either ring shake or radial cracks. Using the results of studies conducted to date, it is possible to suggest that genetic constitution and soil nutrient content are key determinants of a tree's susceptibility to ring shake and thus determine whether it will tend to form radial cracks or ring shake. But it is not yet quite clear what links exist between genetics or nutrients and chestnut wood microstructure, both at the cellular level (geometry of vessels, fibres or rays for example) and at the cellular wall level (compound middle lamella architecture) that could explain this susceptibility to ring shake. At all events, ring shake will also occur mainly where stresses are worse for this kind of rupture. This explains the higher probability of ring shake near the inner third of the stem radius and at the bottom of the felled stem (felling stresses, and first stress recovery in crosscutting). It is probably also the reason why there is a correlation between irregular diametric growth (i.e. high heterogeneity in ring width) and ring shake occurrence. This should lead to high levels of local stress linked to heterogeneity in maturation stresses combined with local changes of wood properties (shrinkage for example), both just after harvesting, or during wood processing. There is also evidence that the older a chestnut tree is, the higher the probability of ring shake occurrence will be. It is not quite clear if this is a consequence of ageing on wood strength, of dimension on growth stress distribution or simply a mechanical effect of the growing probability of irregular growth with passing time, where occasional very dry or cold seasons are responsible for narrow rings.

Considering the aforementioned aspects, and in order to limit the follow-on damage of ring shake, the following could be taken into account wherever quality chestnut wood (with a lower risk of ring shake) has to be produced. There are three points in the wood production process where decision can be made that affect the likelihood of ring shake. The first has to be made when selecting a site. Although chestnut does not like calcareous 
soils, it is better to grow chestnut trees on fertile soils where, in particular, there is enough free calcium. Not only because calcium may reduce the risk of ring shake, but also because a fast and regular growth helps to reduce the risk of ring shake. Coppice stands are to be preferred to high forest because of the short rotation time, but active silviculture is required in order to maintain regular growth and an equilibrated tree shape. The second decision affects individual trees, and involves recognising their genetic constitution as regards radial wood strength so as to eliminate the trees that are prone to ring shake. At present, there are two possible techniques that might help, but both need improvement. The first one is measuring radial strength on wood samples taken directly from the standing trees, e.g. using Fractometer [36] tests. The second method is measuring the radial propagation of ultrasound waves in the stem [35]; there seems to be some relationship between radial wave propagation and the occurrence of ring shake. The third decision is made when the tree is felled. Depending on the kind of fractures observed at the basis of the stem (ring shake or radial crack), it is possible to make a further selection and decide on the further industrial use of the wood. While these measures do not completely exclude the possibility of ring shake, they certainly minimise both the risk and the consequences of ring shake.

\section{FUTURE PROSPECTS}

As we have seen, some aspects of the whole mechanism have yet to be explained and certain relationships have not yet been completely demonstrated. Below we have listed certain points that merit further investigation in order to obtain a better picture of the complex phenomenon that is ring shake:

- different features of ring shake have been recognised. It is likely that the mechanism that leads to each fracture feature has a different origin. A detailed description of this aspect may help in comprehending the mechanism that causes breaking, in particular the type of stress that is principally involved in the development of the fracture as well as the characteristics of the broken material;

- the structure of chestnut wood is conducive to weak wood strength. A better understanding of the relationships between ring shake incidence, anatomical and mechanical wood characteristics and the influence of factors such as genetic constitution and soil may help us better evaluate the risk of ring shake;

- irregularity in chestnut wood seems to influence ring shake. A better description of this effect on wood properties and stresses is needed and should be further investigated. An understanding of irregularity could be beneficial in developing silvicultural model contributing to minimise the risk of ring shake development.

Acknowledgements: We sincerely thank Marco Conedera and Fulvio Giudici for their helpful comments and are grateful to Joseph Gril for reviewing the paper.

\section{REFERENCES}

[1] Alberti M., La cipollatura del castagno: ricerche sperimentali circa la sua localizzazione all'interno dei singoli fusti, Tesi di laurea, Università degli studi di Torino, 1991, pp. 94.

[2] Albrecht W., Untersuchung der Spannungssteuerung radialer Festigkeitsverteilung in Bäumen, Dissertation, Universität Karlsruhe, 1995, pp. 121.

[3] Albrecht W.A., Bethge K.A., Mattheck C., Is lateral strength in trees controlled by lateral mechanical stress?, Journal of Arboriculture 21 (1995) 83-87.

[4] Amorini E., Bruschini S., Fioravanti M., Macchioni N., Manetti M.C., Thibaut B., Uzielli L., Studi sulle cause di insorgenza della cipollatura nel legno di castagno (Castanea sativa Mill.), in: Comunità montana delle Prealpi Trevigiane (ed), Atti del Convegno nazionale sul castagno, Cison di Valmarino (Treviso), 23-25 ottobre 1997, 1998, pp. 269-292.

[5] Archer R., Growth stresses and strain in trees, Springer Verlag Berlin, 1986.

[6] Archer R., Byrnes F.E., On the distribution of tree growth stresses. Part I: An anisotropic plane strain theory, Wood Sci. Technol. 8 (1974) 184-196.

[7] Bamber R.K., The origin of growth stresses: a rebuttal, IAWA Bul. 8 (1987) 80-84.

[8] Beery W.H., Quantitative wood anatomy: relating anatomy to transverse tensile strength, Wood Fiber Sci. 15 (1983) 395-407.

[9] Berrada E., Recouvrance hygro-thermique du bois vert, Thèse, Université des sciences et techniques du Languedoc, Montpellier, 1991, pp. 281.

[10] Boetto G., La cipollatura del castagno: osservazioni in due boschi cedui del Piemonte (Chiusa Pesio CN, Bibiana TO), Tesi di laurea, Università degli studi di Torino, 1991, pp. 104.

[11] Bonenfant M., Croissance et qualité du châtaignier de futaie en Bretagne, Mémoire, SERFOB Bretagne, 1985, pp. 123.

[12] Bourgeois C., Le châtaignier : un arbre, un bois, Institut pour le développement forestier IDF, Paris, 1992. 
[13] Boyd J.D., Tree growth stresses. Part V: evidence of an origin in differentiation and lignification, Wood Sci. Technol. 6 (1972) 251-262.

[14] Burgert I., Die mechanische Bedeutung der Holzstrahlen im lebenden Baum, Dissertation, Universität Hamburg, 2000 , pp. 173.

[15] Chang C.I.J., The cause of ring shake: a review of literature, Quarterly Journal of Chinese Forestry 6 (1972) 69-77.

[16] Chanson B., Approche structurale et histophisiologique du bois de châtaignier (Castanea sativa Mill). Étude préliminaire à celle de la roulure, DEA Sciences forestières, Université de Nancy 1, 1982, pp. 34.

[17] Chanson B., Étude de la variabilité de quelques propriétés physique et anatomique du bois de châtaignier (Castanea sativa Mill). Application à l'étude de la roulure, Thèse, Université des sciences et techniques du Languedoc, Montpellier, 1988, pp. 278

[18] Chanson B., Leban J.M., Thibaut B., La roulure du châtaignier (Castanea sativa Mill.), For. Med. 11 (1989) 15-32.

[19] Cielo P., Incidenza e tipologie della cipollatura in un ceduo di Castagno del Comune di Garessio $(\mathrm{CN})$ : ricerche bibliografiche e sperimentali, Tesi di laurea, Università degli studi di Torino, 1988, pp. 356.

[20] Dumonceaud O., Étude de la fiabilité du fractomètre de Claus Mattheck en vue de son utilisation comme appareil de détection du risque d'apparition de la roulure chez le châtaignier (Castanea sativa Mill.), Mémoire, Université des sciences et techniques du Languedoc, Montpellier, 1994, pp. 80.

[21] Elzière S., Influence de l'éclaircie sur des brins de taillis de châtaignier (Castanea sativa Mill.). Analyse de tige, contraintes de croissance et fissilité du bois, Mémoire, École nationale d'ingénieur des travaux agricoles de Bordeaux, 1995, pp. 57.

[22] Ferrand J.C., La roulure du châtaignier : Note préliminaire, INRA - CNRF Station de recherche sur la qualité du bois, 1980, pp. 15.

[23] Fioravanti M., Caratterizzazione del legno giovanile di castagno (Castanea sativa Mill.): studi su anatomia, densitometria e variazioni dimensionali, Tesi di laurea, Università degli studi di Firenze, 1992, pp. 75.

[24] Fonti P., Studio delle correlazioni tra alcune caratteristiche del soprassuolo e dei polloni di castagno (Castanea sativa Mill.) con l'incidenza e la distribuzione della cipollatura in un ceduo a Novaggio, Ticino, Lavoro di diploma, Politecnico federale di Zurigo, 1997, pp. 88.

[25] Fonti P., Giudici F., Kucera L.J., Ott E., Pöhler E., Studio sulla cipollatura in un ceduo castanile, in: Comunità montana delle Prealpi Trevigiane (ed), Atti del Convegno nazionale sul castagno, Cison di Valmarino (Treviso), 23-25 ottobre 1997, 1998, pp. 293-302.

[26] Fournier M., Bordonne P.A., Guitard D., Growth stress patterns in tree stems: A model assuming evolution with the tree age of maturation strains, Wood Sci. Technol. 24 (1990) 131-142.

[27] Fournier M., Chanson B., Thibaut B., Guitard D., Mécanique de l'arbre sur pied : modélisation d'une structure en crois- sance soumise à des chargements permanents et évolutifs. 1. Analyse des contraintes de support, Ann. Sci. For. 48 (1991) 513-525.

[28] Fournier M., Chanson B., Thibaut B., Guitard D., Mécanique de l'arbre sur pied : modélisation d'une structure en croissance soumise à des chargements permanents et évolutifs. 2. Analyse tridimensionnelle des contraintes de maturation, cas du feuillu standard, Ann. Sci. For. 48 (1991) 527-546.

[29] Fournier M., Chanson B., Thibaut B., Guitard D., Mesures de déformation résiduelles de croissance à la surface des arbres en relation avec leur morphologie. Observations sur différentes espèces, Ann. Sci. For. 51 (1994) 249-266.

[30] Frascaria N., Étude de la diversité génétique du châtaignier (Castanea sativa Mill.) en île de France : essai de corrélation avec des marqueurs morphologique, phénologique et de qualité du bois (roulure), DEA d'Écologie générale, Université de Paris-Sud, 1987, pp. 34.

[31] Frascaria N., Variabilité génétique d'un arbre forestier : le châtaignier (Castanea sativa Mill.), Thèse, Université de Paris-Sud, 1991, pp. 122.

[32] Frascaria N., Chanson B., Thibaut B., Lefranc M., Génotypes et résistance mécanique radiale du bois de châtaignier (Castanea sativa Mill.) : Analyse d'un des facteurs explicatifs de la roulure, Ann. Sci. For. 49 (1992) 49-62.

[33] Freyssac C., Laroche A., Carlue M., Morvan H., Contribution à l'étude de la roulure chez le châtaignier : étude expérimentale des conséquences d'amendements calciques. II - Effet du calcium sur le contenu pectique du bois, Annales Scientifiques du Limousin 10 (1994) 35-43.

[34] Freyssac C., Rahmani A., Carlue M., Verger J.P., Morvan H., Contribution à l'étude de la roulure chez le châtaignier : étude expérimentale des conséquences d'amendements calciques. I - Relation entre la composition minérale du milieu et celle de jeunes plants, Annales Scientifiques du Limousin 10 (1994) 25-34.

[35] Giudici F., Fonti P., Pöhler E., Sandoz J.L., Qualità del legname di castagno: diagnosi della cipollatura per mezzo di ultrasuoni, in: Comunità montana delle Prealpi Trevigiane (ed), Atti del Convegno nazionale sul castagno, Cison di Valmarino (Treviso), 23-25 ottobre 1997, 1998, pp. 259-267.

[36] Götz K.O., Mattheck C., Studies on the strength of green trees using the fractometer III: model description and user's manual, Wissenschaftlichen Berichte, Forschungszentrum Karlsruhe, 1999, pp. 15.

[37] Grant G.T., Morris E.R., Rees D.A., Smith P.J.C., Thom D., Biological interaction between polysaccharides and divalent cations: the egg-box model, FEBS Letters 32 (1973) 195-198.

[38] Gril J., Berrada E., Thibaut B., Recouvrance hygrothermique du bois vert. II - Variations dans le plan transverse chez le châtaignier et l'épicea et modélisation de la fissuration à cœur provoquée par l'étuvage, Ann. Sci. For. 50 (1993) 487-508.

[39] Gril J., Thibaut B., Tree mechanics and wood mechanics: relating hygrothermal recovery of green wood to the maturation process, Ann. Sci. For. 51 (1994) 329-338. 
[40] Gril J., Thibaut B., Berrada E., Martin G., Recouvrance hygrothermique du bois vert. I - Influence de la température : Cas du jujubier (Ziziphus lotus (I) Lam.), Ann. Sci. For. 50 (1993) 57-70.

[41] Guiot A., Contribution à l'étude du châtaignier à bois en Bretagne, SRAF de Bretagne, 1983, pp. 37.

[42] Jullien D., Analyse expérimentale et numérique des contraintes résiduelles dans un matériau élastique orthotrope élaboré par couches successives. Cas d'un disque de bois vert, Thèse, Université des sciences et techniques du Languedoc Montpellier, 1995, pp. 214.

[43] Jullien D., Gril J., Mesures des déformations bloquées dans un disque de bois vert. Méthode de la fermeture, Ann. Sci. For. 53 (1996) 955-966.

[44] Keller R., Thiercelin F., Influence des gros rayons ligneux sur quelques propriétés du bois de hêtre, Ann. Sci. For. 32 (1975) 113-129.

[45] Kübler H., Hygrothermal recovery under stress and release of inelastic strain, Wood Sci. 6 (1973) 78-86.

[46] Kübler H., Role of moisture in hygrothermal recovery, Wood Sci. 5 (1973) 198-204.

[47] Kübler H., Growth stresses in trees and related wood properties, Forest Prod. Abstr. 10 (1987) 61-119.

[48] Lachaussée E., Note upon shake and forest crack of Quercus robur, For. Abstr. 15 (1953) 1598.

[49] Laroche A., Approche expérimentales de la nutrition du châtaignier : Influence d'apports nutritifs sur la croissance des plants, sur la distribution des éléments minéraux dans les organes et sur les caractéristiques générales des pectines, chez des jeunes arbres cultivés sous serre, Thèse, Université de Limoges, 1997, pp. 188.

[50] Laroche A., Freyssac V., Rahmani A., Verger J.P., Morvan H., Growth and mineral content of chestnut trees under controlled conditions of nutrition, Ann. Sci. For. 54 (1997) 681-693.

[51] Leban J.M., Contribution à l'étude de la roulure du châtaignier, Thèse, Institut National Polytechnique de Lorraine, 1985, pp. 164.

[52] Macchioni N., Studi sulla cipollatura del castagno (Castanea sativa Mill.): metodologie per la valutazione della coesione trasversale del legno, Tesi di Laurea, Università degli studi di Torino, 1992, pp. 102.

[53] Macchioni N., Mechanical strength and ring shake in chestnut (Castanea sativa Mill.), For. Med. 16 (1995) 67-73.

[54] Macchioni N., Pividori M., Ring shake and structural characteristics of a chestnut (Castanea sativa Mill.) coppice stand in northern Piedmont (Northwest Italy), Ann. Sci. For. 53 (1996) 31-50.
[55] Mattheck C., Albrecht W., Dietrich F., Die Biomechanik der Holzstrahlen, Allg. Forst- Jagdztg. 165 (1994) 143-147.

[56] Mattheck C., Schwarze M.R., Die Holzstrahlen als getarnte I-Balken in einem mechanischen Ersatzmodell für Holz, Allg. Forst- Jagdztg. 165 (1994) 197-201.

[57] Movassaghi E., Mothe F., Thibaut B., Étude de la faisabilité du déroulage de brins de taillis de châtaignier, Laboratoire de mécanique générale des milieux continus, Université de Montpellier, 1987, pp. 50.

[58] Pozzi F., Studio anatomico comparativo sulle modalità di frattura del legno di castagno (Castanea sativa Mill.): campioni affetti da cipollatura e campioni rotti meccanicamente, Tesi di laurea, Università degli studi di Torino, 1996, pp. 90.

[59] Ranger J., Felix C., Bouchon J., Nys C., Ravart M., Dynamique d'incorporation du carbone et des éléments nutritifs dans un taillis simple de châtaignier (Castanea sativa Mill.), Ann. Sci. For. 47 (1990) 413-433.

[60] Rothman J.K., Greenland S., Modern epidemiology, Lippincott-Raven Philadelphia, 1998.

[61] Saya I., Indagini sulla cipollatura del legno di Castagno e di Abete bianco, in: Contributi scientifico-pratici per una migliore conoscenza e utilizzazione del legno, CNR, I.p.l.r.s.l., Firenze, 1962, pp. 37-41.

[62] Staglianò N., Caratterizzazione ultrastrutturale del legno di castagno: studi sull' angolo di inclinazione delle microfibrille, Tesi di laurea, Università degli studi di Firenze, 1992, pp. 75 .

[63] Thibaut B., Chanson B., Fournier M., Jullien D., Valorisation du bois de châtaignier : prévoir et réduire les risques de roulure à la production, Rapport Final, Institut pour le Développement Forestier, 1995, pp. 48.

[64] Thibaut B., Fournier M., Jullien D., Contraintes de croissance, recouvrance différée à l'étuvage et fissuration des grumes : cas du châtaignier, For. Med. 16 (1995) 85-91.

[65] Uzielli L., New silvicultural methods and innovative technologies for the valorisation of Chestnut wood as a prime resource for industry, EEC Research Program, Final report, Task C, Operative Unit 06, Forest Program Chestnut - Task C, 1994, pp. 38.

[66] Verger J.P., Domain P., Fournier J.M., Maisonier C., Djomo J.E., Importance du calcium dans le développement in situ du taillis de châtaignier en Limousin, Ann. Sci. For. 10 (1994) 13-24.

[67] Verger J.P., Morvan H., Fournier J.M., Matga F., Maisonier C., Freyssac V., Desjobert T., Domain P., Nutrition minérale du châtaignier (Castanea sativa Mill.) : rôle dans le développement de la roulure, 1993, pp. 36. 